
Spinoza and Other Heretics

THE MARRANO OF REASON 



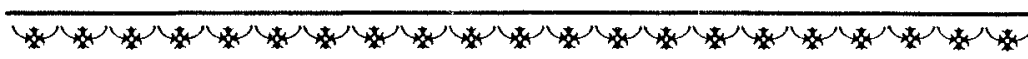

Spinoza and

\section{Other Heretics}

THE MARRANO

OF REASON

YIRMIYAHU YOVEL

PRINCETON UNIVERSITY PRESS

- 
Copyright $(\mathcal{C} 1989$ by Princeton University Press

Published by Princeton University Press, $4 \mathrm{I}$ William Street,

Princeton, New Jersey $0854^{\circ}$

In the United Kingdom: Princeton University Press,

Oxford

\section{All Rights Reserved}

Library of Congress Cataloging-in-Publication Data

Yovel, Yirmiahu.

Spinoza and other heretics / Yirmiyahu Yovel; with a new afterword by the author.

p. $\mathrm{cm}$.

Includes bibliographical references and indexes.

Contents: v. I. The Marrano of reason-

$v$ v. 2. The adventures of immanence.

ISBN 0-69I-07344-9 (v. r: alk. paper)-

ISBN 0-69I-02078-7 (v. I: pbk.: alk. paper)-

ISBN 0-691-07346-5 (v. 2: alk. paper)-

ISBN 0-69I-02079-5 (v. 2: pbk.: alk. paper)

I. Spinoza, Benedictus de, 1632-1677. 2. Marranos. 3. Immanence

(philosophy)-History-17th century. I. Title.

$$
\begin{gathered}
\text { B3998. Y67 1992 } 9^{1-32030} \\
\text { 199'.492-dc20 }
\end{gathered}
$$

First Princeton Paperback printing, with corrections and a new afterword by the author, 1992

$$
\begin{array}{lllll}
9 & 8 & 7 & 6 & 5
\end{array}
$$

Publication of this book has been aided by a grant from the Whitney Darrow Fund of Princeton University Press

This book has been composed in Linotron Bembo

Princeton University Press books are printed on acid-free paper, and meet the guidelines for permanence and durability of the Committee on Production Guidelines for Book

Longevity of the Council on Library Resources

\section{Printed in the United States of America}

Acknowledgment is gratefully made to Dover Publications for permission to quote from The Chief Works of Benedict Spinoza, tr. R. H. Elwes (I95I); and the University of California Press for quotes from Fernando de Rojas, The Celestina, tr. L. B. Simpson (197I). "Baruch Spinoza," by Jorges Luis Borges and translated from the Spanish by Yirmiyahu Yovel, is published by arrangement with the Estate of Jorge Luis Borges. All rights reserved. 
For Jonathan 


\section{Baruch Spinoza}

Like golden mist, the west lights up The window. The diligent manuscript Awaits, already laden with infinity. Someone is building God in the twilight. A man engenders God. He is a Jew Of sad eyes and citrine skin. Time carries him as the river carries A leaf in the downstream water.

No matter. The enchanted one insists And shapes God with delicate geometry. Since his illness, since his birth, He goes on constructing God with the word. The mightiest love was granted him Love that does not expect to be loved.

-Jorge Luis Borges, translated by Yirmiyahu Yovel 